\title{
Integrating Place-Based Education in Biology Learning through Inquiry to Improve Student's Cognitive Ability and Scientific Attitudes in Sumbawa
}

\author{
$1^{\text {st }}$ Ari Ashari \\ Biology department \\ Universitas Negeri Malang \\ Malang, Indonesia \\ ari_ashari618@yahoo.co.id \\ $4^{\text {th }}$ Hadi Suwono \\ Biology department \\ Universitas Negeri Malang \\ Malang, Indonesia
}

\author{
$2^{\text {nd }}$ Sakila Pujiank \\ Biology department \\ Universitas Negeri Malang \\ Malang, Indonesia \\ $5^{\text {th }}$ Betty Lukiati \\ Biology department \\ Universitas Negeri Malang \\ Malang, Indonesia
}

\author{
$3^{\text {rd }}$ Ibrohim \\ Biology department \\ Universitas Negeri Malang \\ Malang, Indonesia
}

\begin{abstract}
The integrating of place-based education needs to make the learning activity more meaningful and make student can apply their knowledge to solve the real problem around them. The purpose of this research is to describe the integrating of place-based education in biology learning through inquiry to improve student's cognitive ability and scientific attitude in Sumbawa. The result shows that integrating environmental capacity such as Rawa Lake and Beringin Sila River into learning activity through inquiry can make student cognitive ability increase. By learning directly from the environment, the student has a sign of progress in scientific attitudes in each learning activity. They release that environmental sustainability is their responsibility. So they try to keep the environment by giving the idea to solve the environmental problem.
\end{abstract}

Keywords-place-based education, inquiry, cognitive ability, scientific attitude

\section{INTRODUCTION}

Scientific learning, especially biology has been regarded as complex and challenging learning by students [1-3]. Nowadays, to teach biology learning is not only let the student to read and to listen to the teacher in the front of the class, but teaching biology is more than transfer a new knowledge for the student. The student must be active learner and teacher must be the facilitator to facilitate student to achieve the learning goals. In modern school, the application of biology learning disconnecting with the real problem in real life. That phenomena make the student challenging to apply their knowledge in real life. The learning of biology must be integrated with the real problem to make meaningful learning and make the student more understand about the concept of biology. That can happen in all level of biology learning system include in the educational system of Sumbawa. Based on interview and observation in the senior high school of Sumbawa, the result shows that cognitive ability and scientific attitudes include low category [4,5]. All this time, the teacher in biology learning teach the student with conventional and teacher center technique. The proportion of student to include in the process of learning is reduced. The teacher cannot present the learning process that can make the student have a thinking process. Many of student learn biology by reading a book and discussion. In biology learning especially about scientific attitude, the teacher in Sumbawa never make assessment about that. Based on observation the scientific attitudes such as curiosity, cooperation, open-mindedness, accuracy, responsibility, intellectually honest, and environmental caring are not appearing in the learning process. To make student can improve their learning outcome, the one of solution that can solve the problem is integrating place-based education in the learning process.

Place-Based Education (PBE) is an approach to learning that takes advantage of geography to create authentic, meaningful and engaging personalized learning for students. More specifically, Place-Based Education is defined by the Center for Place-Based Learning and Community Engagement as an immersive learning experience that "places students in local heritage, cultures, landscapes, opportunities and experiences, and uses these as a foundation for the study of language arts, mathematics, social studies, science and other subjects across the curriculum [6]. Placebased education enables personalized learning by giving student "voice and choice "in determining what how, when, and where they learn; tailoring learning to each student's strengths, need, and interests; ensuring mastery of high academic standard; and promoting student agency [6]. There are many of researches that present result about place-based education can increase the cognitive ability, scientific attitudes, critical attitudes, scientific skill for the student as the step to make sustainability development for next generation [7-11].

Sumbawa has an environmental capacity to facilitate student to learn about biology. In Sumbawa, like Utan has a river and in Taliwang has a lake. Two of those can be integrated into the learning process to make meaningful learning for a student in biology by the teacher. The river in 
Utan has a unique characteristic. The river that we can call with Beringin Sila River is the main river in Utan that people always use to daily needs such sanitation activity, take a bath, washing clothes, fishing and agricultural activity [12]. The Lake that we call with Rawa Lake has many of flora and 25 species of fauna and also the largest lake in West Nusa Tenggara [13]. The teacher can utilize the environmental (Place-Based Education) to teach the concept about biology in diversity and ecosystem concept through the learning process. To teach the student, the teacher needs the learning model that suitable to teach a concept. One of the models that can teacher use to teach is an inquiry model. Inquiry-based learning is an educational strategy in which students follow methods and practices similar to those of professional scientists to construct knowledge [14]. That model can give the advantage in the learning process to make a student be active learning, can increase the cognitive ability, teach the student to increase the problem-solving skill, scientific skill, scientific attitudes, critical thinking, to teach the student to communicate their observation result, metacognition, and personal responsibility [14-17].

\section{METHODS}

This research is descriptive quantitative. This research aims to describe the cognitive ability and scientific attitudes of students in the senior high school in Sumbawa. Samples of this research are students of senior high school 1 Utan that representative of Sumbawa and student of Al-Ikhlas Taliwang senior high school that representative of West Sumbawa. Data were collected from students by test to measure the cognitive ability and observation sheet to measure the scientific attitude in diversity and ecosystem concept. The analyzing of cognitive ability data use gain score and analyzing of scientific attitude use the descriptive technique.

\section{RESULTS AND DISCUSSION}

The result shows that improvement of student cognitive ability in diversity and ecosystem concept of biology. Based on data that present in Table 1, the result shows that each concept of biology has improvement in the post-test.

Table 1. Data of student cognitive ability

\begin{tabular}{lcccc}
\hline $\begin{array}{c}\text { Concept of } \\
\text { biology }\end{array}$ & $\begin{array}{c}\text { Ideal } \\
\text { score }\end{array}$ & $\begin{array}{c}\text { Pretest } \\
\text { average }\end{array}$ & $\begin{array}{c}\text { Posttest } \\
\text { average }\end{array}$ & $\begin{array}{c}\text { N-gain } \\
\text { score }\end{array}$ \\
\hline Diversity & 100 & 44,19 & 69,35 & 0,45 \\
Ecosystem & 100 & 47,73 & 60,37 & 0,24 \\
\hline
\end{tabular}

The integrating of place-based education through inquiry learning make student more understand about the concept. The student can learn directly with the environment. They can do anything like observation, investigation, exploration that focus on solving the real problem from the environment that can help them to contribute to their social problem. This concept of learning can make student as next generation to make environmental sustainability.

Place-based education is the alternative solution in biology learning. By the learning activity from real conditions are close to the student such as lake and river, the teacher in the learning process has a position as a facilitator that help the student to understand about the concept correctly $[18,19]$. That activity put the student as a central learner that can make them active and can improve a student's cognitive ability [20,21].

\section{b. Scientific attitudes}

In scientific attitudes, the student shows many of the progress in every learning activity. They show improvement in each indicator of scientific attitudes such as curiosity, cooperation, open-mindedness, accuracy, responsibility, honesty and environmental caring. Based on data that show at the Fig. 1 the student has improved in each learning activity. By the utilization of Rawa Lake Taliwang into inquiry activity, the student can learn the diversity concept of biology and also have the capability in scientific attitudes.

\section{a. Cognitive Ability}

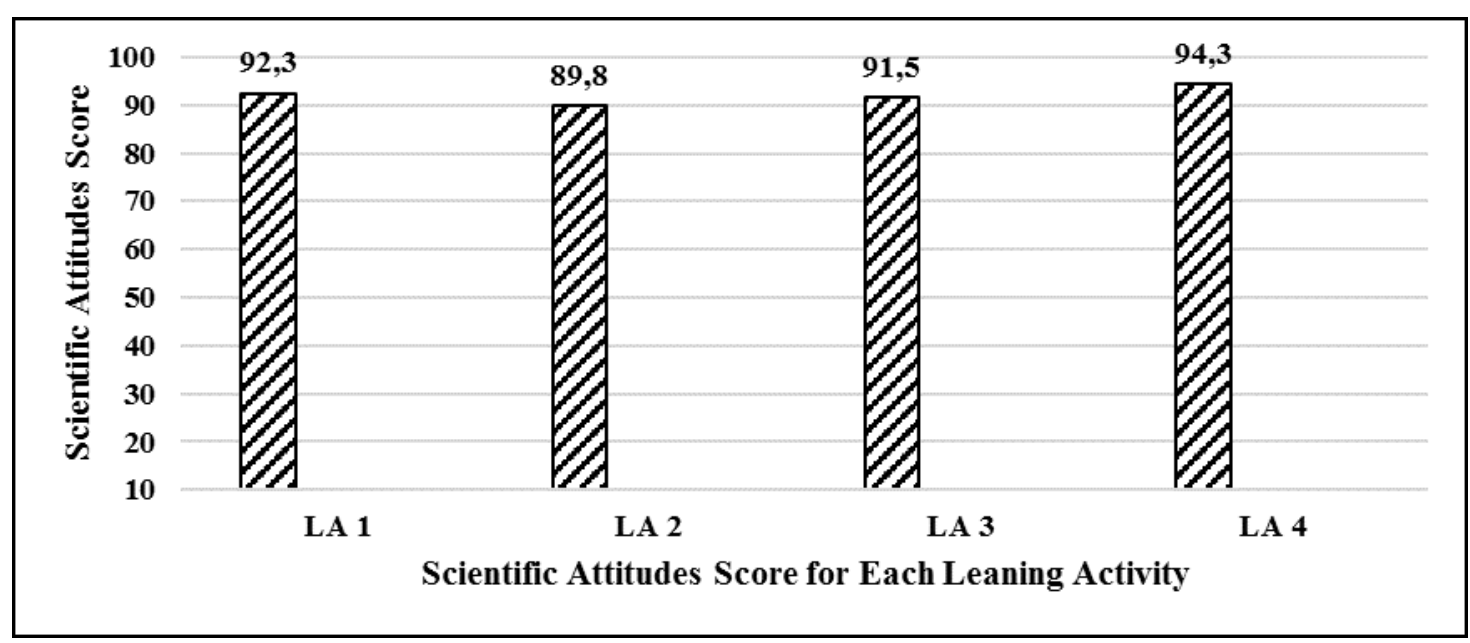

Fig. 1. Scientific Attitude Score for Every Learning Activity (LA) in Diversity Concept of Biology 


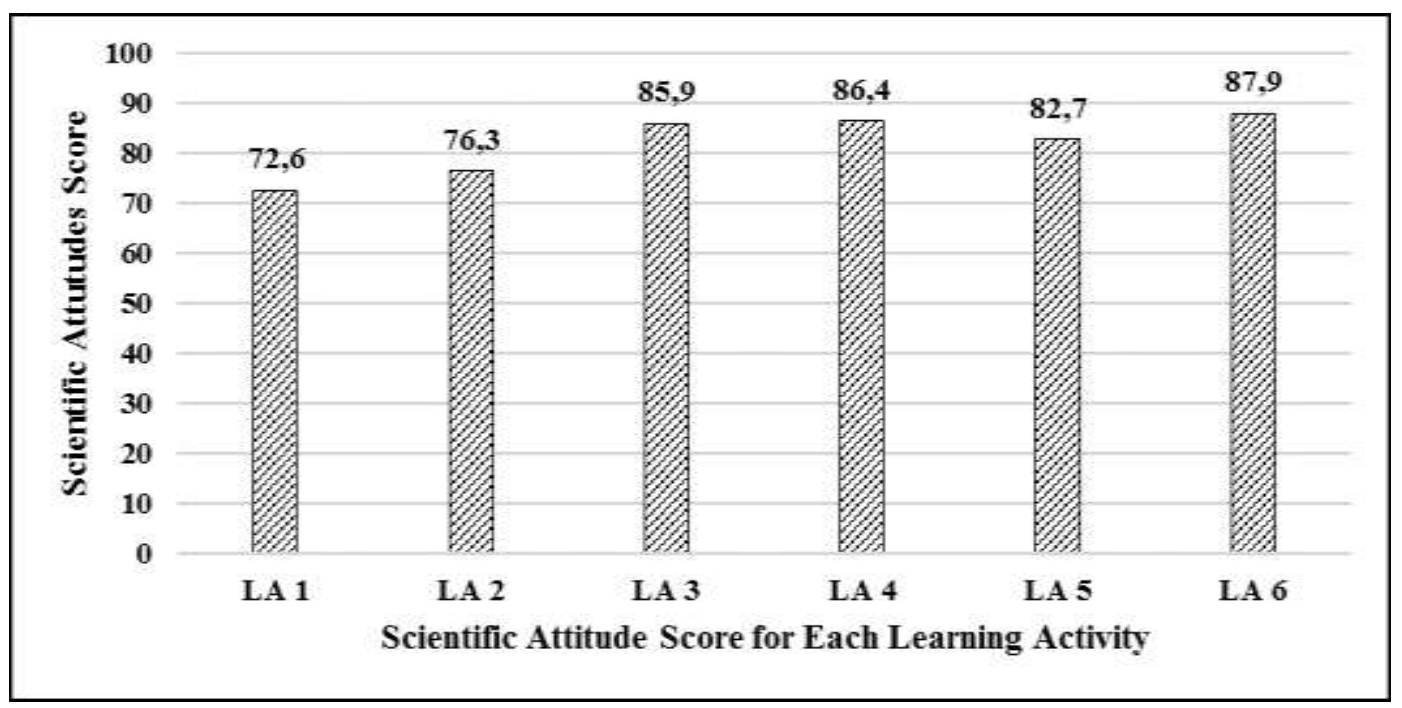

Fig. 2 Scientific Attitude Score for Every Learning Activity (LA) in Ecosystem Concept of Biology.

The result in another concept of biology such as ecosystem has improved also. By the utilization of environmental capacity through inquiry learning, the student can explore the Beringin Sila River to find the concept of ecosystem. In learning activity of the ecosystem, the student makes a group to do the inquiry learning that can increase their cooperative attitude and make sense of their curiosity can increase also. Place-based education through inquiry can make a student also have the open-mindedness, accuracy, responsibility, honesty and environmental caring. They release that environmental sustainability must be their responsibility. The experience that they get from the environment make them know the real problem that happens around them. So, they can make the right decision to save their environment.

According to the result of the scientific attitude score in each subject matter, integrating place-based education which combined by inquiry in biology learning can improve students' scientific attitude. This statement supported by research conducted by Natalina et al. (2013) and Sutama et al. (2014) which states that inquiry learning can improve students' scientific attitude [22,23]. The utilization of the environment in the learning process through inquiry is a learning approach that seeks to increase student involvement through environmental empowerment as a learning resource including developing students' scientific attitude. Learning with the environmental approach in essence closer and integrate students with their environment so that they have a sense of love, care, and responsibility to the environment [18].

\section{CONCLUSION}

Based on the finding and discussion, this research concludes that integrating place-based education in biology learning through inquiry can improve the student's cognitive ability and scientific attitudes.

\section{REFERENCES}

[1] Hidayatussadah, "Pengaruh Penggunaan Pendekatan Ilmiah (Scientific Approach) dalam Pembelajaran Terhadap Hasil Belajar Siswa Kelas XII
TITL 1 SMK Negeri 7 Surabaya Pada Standar Kompetensi Mengoperasikan Sistem Kendali Elektromagneti," Jurnal Pendidikan Teknik Elektro, vol. 3(2), pp. 25-29, 2014.

[2] Sianturi, "Analisis Kesulitan Belajar dan Hubungannya dengan Hasil Belajar Siswa pada Pembelajaran Biologi Siswa Kelas X di SMA Negeri 1 Sidikalang tahun Pembelajaran 2015/2016," Tesis, http://digilib.unim ed.ac.id/5065/, Accessed date December 252016.

[3] Umiyati, Susilo, "Perbandingan Faktor-Faktor Penyebab Kesulitan Belajar antara Siswa Kelas X.6 dengan Kelas X.7 pada Mata Pelajaran Biologi Materi Virus (Study Kasus di SMA N 1 Sukagumiwang Indramayu)," JUPEMASI-PBIO, vol. 1(1), 2014.

[4] Ashari, A., "Kajian Pendekatan Saintifik dan Pemanfaatan Sumber Belajar Potensi Lokal dalam Implementasi Kurikulum 2013 pada Pembelajaran Biologi SMA di Kabupaten Sumbawa Barat”, Prosiding Seminar Nasional ke-3 Biologi, IPA, dan Pembelajarannya, 2016

[5] Pujiank,S., "Kajian mengenai Pendekatan Saintifik dan Pemanfaatan Sumber Belajar Potensi Lokal dalam Implementasi Kurikulum 2013 pada Pembelajaran Biologi SMA di Kabupaten Sumbawa", Prosiding Seminar Nasional ke-3 Biologi, IPA, dan Pembelajarannya, 2016.

[6] Getting smart, "What Is Place-Based Education and Why Does It Matter?", http://gettingsmart.com, 2017.

[7] Ernst, J. \& Monroe, M., "The Effects of Environmental-Based Education on Student' Critical Thinking Skills and Disposition Toward Critical Thinking," Environmental Education Research, vol.10(4), pp. 500-522, 2004.

[8] Marijan, "Pemanfaatan Lingkungan Sekitar Sekolah Sebagai Sumber Belajar Keanekaragaman Tumbuhan Bagi Siswa Kelas VII Semester 2 SMP Negeri 5 Wates Kulun Progo," Prosiding Seminar Nasional Penelitian Pendidikan dan Penerapan MIPA Fakultas MIPA, Universitas Negeri Yogyakarta, pp. 1-10, 2012.

[9] Sribekti, A., "Pengembangan Pembelajaran Ekosistem Berbasis Inkuiri Terbimbing dengan Sumber Belajar Waduk Lahor untuk Meningkatkan Keterampilan Proses Sains, Sikap Ilmiah, dan Hasil Belajar Kognitif Siswa Kelas VII SMP Negeri 1 Selorejo Kabupaten Blitas," Malang: Pascasarjana UM, unpublished thesis, 2016

[10] Hariyadi, D., "Pengembangan Pembelajaran Ekosistem Berbasis Inkuiri Terbimbing dan Potensi Sungai Wajagesang untuk Meningkatkan Penguasaan Konsep, Keterampilan, dan Sikap Ilmiah Siswa Kelas VII SMP Negeri 4 Kopang," Malang: Pascasarjana UM, unpublished thesis, 2016.

[11] ASEAN Environmental Education Action Plan 2014-2018

[12] Department of River Area West Nusa Tenggara, Beringin Sila Utan, Mataram: Department of River Area West Nusa Tenggara, 2014.

[13] Department of Tourism and Economic Creative West Sumbawa, http://disparekraf.sumbawabaratkab.go.id/danau-lebo.html, Accessed on Januari 2017.

[14] Pedaste, Margus, Mario Maeots, Leo A Siiman, Ton de Jong, Sisswa A,N van Riesen, Ellen T. Kamp. Costantinos C, Manoli, Zacharias C, 
Zacharia, Eleftheria Tsourlidaki, "Phase of Inquiry-Based Learning: Definitions and the Inquiry Cycle," Educational Research Review, vol. 14 pp. 47-61, 2015.

[15] Lati, W., Supasom, S. \& Promarak, V. 2012. Enhancement of Learning Achievement and Integrated Science Process Skills Using Science Inquiry Learning Activities of Chemical Reaction Rates. Procedia Social and Behavioral Sciences, vol. 46, pp. 4471—4475, 2012.

[16] Nath, S. \& Thomas, S., "Enhancing Science Process Skills and Scientific Attitude and Analyzing their Interactions: An Intervention through Inquiry Learning Approach," International Journal of Scientific Research, vol. 1(1), pp. 37-42, June 2012.

[17] E. Remziye, Y. Simsekli, S. Calis, Z. Ozdilek, S. Gocmencelebi, M. Sanli, "The Effect of Inquiry - Based Science Teaching on Elementary School Students'Science Process Skill and Science Attitudes", Bulgarian Journal of Science and Education Policy, vol. 5(1), 2011.

[18] Mulyasa, E., "Guru Dalam Implementasi Kurikulum 2013”, Bandung: Remaja Remaja Rosdakarya, 2015.

[19] Ibrohim, "Pengembangan Pembelajaran IPA/Biologi Berbasis Discovery/Inquiry dan Potensi Lokal Untuk Meningkatkan Keterampilan dan Sikap Ilmiah Serta Menumbuhkan Jiwa Kewirausahaan," Prosiding Semnas Sains dan Entrepreneurship II, pp. $1-9,2015$.

[20] Azizahwati, et.al. Pengembangan Modul Pembelajaran Fisika SMA Berbasis Kearifan Lokal untuk Meningkatkan Hasil Belajar Siswa," Prosiding Pertemuan Ilmiah XXIX HFI Jateng \& DIY, pp. 70-73, 2015.

[21] Saputra A., Wahyuni, S., Handayani R, D., "Pengembangan Modul IPA Berbasis Kearifan Lokal Daerah Pesisir Puger pada Pokok Bahasan Sistem Transportasi di SMP," Jurnal Pembelajaran Fisika, vol. 5(2), pp. 182-189, 2016.

[22] Natalina, M. Yusuf, Y., "Ermadianti, Penerapan Strategi Pembelajaran Inkuiri Terbimbing untuk Meningkatkan Sikap Ilmiah dan Hasil Belajar Biologi Siswa kelas VIII SMP Negeri 14 Pekanbaru Tahun Ajaran 2012/2013," Jurnal Biogenesis, vol. 9(2), pp. 28-38, 2013.

[23] Sutama, N,I. Arnyana, P.B.I., Swasta, J.B.I., "Pengaruh Model Pembelajaran Inkuiri Terbimbing Terhadap Keterampilan Berpikir Kritis dan Kinerja Ilmiah pada Pelajaran Biologi Kelas XI IPA SMA Negeri 2 Amlapura. E-Journal Program Pascasarjana Universitas Pendidikan Ganesa, vol. 4pp. 12-16, 2014. 